\title{
Tannin content affects negatively nutritive value of pea for monogastrics*
}

\author{
S. Smulikowska, B. Pastuszewska, E. Święch, A. Ochtabińska, \\ A. Mieczkowska, V. C. Nguyen and L. Buraczewska
}

\author{
The Kielanowski Institute of Animal Physiology and Nutrition, \\ Polish Academy of Sciences \\ 05-110 Jablonna, Poland
}

(Received 10 January 2001; accepted 7 August 2001)

\section{ABSTRACT}

Nine Polish varieties of pea ( $P$. sativum L.) differing in flower colour, from white to purple, were evaluated for chemical and amino acid composition and in vitro for predicted ileal digestibility of protein ( $\mathrm{pdN}$ ) and predicted digestibility of energy ( $\mathrm{pdE}$ ) for pigs. In selected varieties differing in tannin content the apparent metabolizable energy value corrected for zero $N$ balance $\left(A M E_{N}\right.$ ), apparent digestibility of protein and fat and effect of enzymes reducing viscosity of digesta on this parameters were estimated in chickens; apparent metabolizable energy value (AME), true digestibility and biological value of protein was determined in rats.

Tannin content had most pronounced negative effect on protein digestibility in chicken $(r=-0.93$; $\mathrm{P}<0.05)$ and rats $(\mathrm{r}=-0.89 ; \mathrm{P}<0.05)$, pdN for pigs $(\mathrm{r}=-0.98 ; \mathrm{P}<0.001)$ as well as $\mathrm{AME}_{\mathrm{N}}$ for chicken $(r=-0.99 ; P<0.001)$ and $A M E$ for rats $(r=-0.95 ; P<0.01)$, while nutrient content in peas had no significant effect on measured parameters. $A M E_{N}$ values of pea did not depend on supplementation of pea-containing diet with xylanase.

Seeds of coloured-flowered cultivars, which are rich in tannins are less effectively utilized by monogastric animals than white-flowered ones. The degrec of decline in nutrient utilization depends on tannin content in the seeds, which is correlated with the colour of the flowers.

KEY WORDS: Pisum sativtm, tannins, chickens, rats, energy value, protein value

* Supported in part by the State Committec for Scientific Research, Grant No. 5 P06E 03115 Presented to the $4^{\text {th }}$ European Conference on Grain Legumes, Kraków (Poland), 8-12 June, 2001 


\section{INTRODUCTION}

An importance of pea as a component of feed mixtures for poultry and pigs recently increased, as pea protein may substitute part of meat meal protein, withdrawn from animal diets for sanitary reasons. Pea production increased considerably in Europe and many research programmes were established to study the composition of different types and cultivars of pea and relationships between composition criteria and nutritional value of pea (Bastianelli et al., 1998; Grosjean et al., 1998a,b, 1999). In Poland, among seventeen registered cultivars of pea grown on light soils, twelve (Wiatr, 1999) belongs to a colour-flowered ( . sativum L. ssp. arvense), yielding seeds with higher tannin content than white-flowered varieties $(P$. sativum L. ssp. sativum). Tannins are recognized as a main antinutrient in colour-flowered field beans and peas (Savage, 1989). Comparison of chemical composition and ileal digestibility of amino acids for pigs of 10 Polish cultivars of pea was done by Gdala et al. (1992), the content of nutrients and antinutritional substances in 15 cultivars of white-flowered pea was determined by Zduńczyk et al. (1997).

The objective of the present study was to compare the composition and nutritional value of peas differing in flowers colour and tannin content in seeds, and to assess effects of feeding them on selected parameters of gastro-intestinal functions in chicken and rats. In experiment with chicken the effects of supplementation of pea diets with xylanase were also determined.

\section{MATERIAL AND METHODS}

Seeds (sowing grade) of 9 Polish cultivars of spring pea from 1998 harvest year were obtained from plant breeding stations and comprised the white-flowered: Mazurek, Albatros, Agra, Piast, the red-flowered: Bart, Idol, Dawo, Wiato and the purple-flowered Żuraw.

In vivo tests

The experiments were complied with obligatory ethical regulations concerning animal experimentation and care of animals under study.

Experiments on chickens. Seeds of 5 cultivars differing in tannin content - Albatros, Piast, Idol, Wiato and Żuraw were used. Experiment was done on 98 fourweek-old broiler chickens (Cobb 500) with a mean initial body weight of $1032 \mathrm{~g}$. The birds were housed individually in balance cages, 8 (test groups) or 9 (control groups) birds per treatment. Two control groups were fed basal diets (A or B) containing (in $\mathrm{g} / \mathrm{kg}$ ): wheat, 590; soyabean oil meal, 334; rape seed oil, 3; mineral- 
vitamin mixture, 4.4; L-lysine, 0.1 and DL-methionine, 0.1. Diet A was not supplemented, while diet B was supplemented with $1 \mathrm{~g}$ of enzyme preparation BioFeed Wheat CT (Novo Nordisk) containing $1000 \mathrm{FXU}$ xylanase/g according to producer. Remaining groups were fed test diets composed of basal diet $\mathrm{A}$ or $\mathrm{B}$ and ground pea combined in proportions as 1:1 on DM basis. To the basal and test diets $3 \mathrm{~g} \mathrm{Cr}_{2} \mathrm{O}_{3}$ per $\mathrm{kg} \mathrm{DM}$ was added as a marker. All diets were cold pelleted.

The diets were fed at the level of $100 \mathrm{~g} / \mathrm{bird} / \mathrm{day}$, in three meals. After 2 days of preliminary feeding the birds were fasted during $17 \mathrm{~h}$ then fed on the same diets for 4 days, and fasted for $17 \mathrm{~h}$. Feed intake was recorded and excreta was collected during last $96 \mathrm{~h}$ of the experiment. Excreta were immediately frozen and kept at $-18^{\circ} \mathrm{C}$ for further analysis. Apparent metabolizable energy value corrected for zero $\mathrm{N}$ balance $\left(\mathrm{AME}_{\mathrm{N}}\right)$, apparent digestibility of protein, fat and organic matter retention was calculated for basal and test diets. Respective values for evaluated cultivars of pea were calculated by difference method according to Campbell et al. (1983) and Pesti and Ware (1986), the values obtained for basal diets A or B were used as a reference.

At the end of the experiment all birds were killed by decapitation, digestive tract was removed, small intestine was ligated to avoid the post-mortem movement of digesta, and intestinal contents were withdrawn by gently finger stripping. The jejunal digesta were collected to tubes placed on ice, centrifuged at $10000 \mathrm{xg}$ for $10 \mathrm{~min}$, the supernatants were withdrawn and their viscosity determined using a Brookfield digital viscometer (Model DV-II $+\mathrm{LV}$ ) maintained at $40^{\circ} \mathrm{C}$. The ileal digesta from two birds was pooled, mixed with distilled water $1: 1 \mathrm{w} / \mathrm{w}$ and $\mathrm{pH}$ was immediately measured on WTW 340 A digital pH-meter.

Experiments on rats. Seeds of 6 cultivars differing in tannin content: Albatros, Piast, Idol, Dawo, Wiato and Zuraw were used in two experiments. In experiment 1 true digestibility (TD) and biological value (BV) of protein was determined by the Thomas-Mitchell method according to the procedure described by Smulikows$\mathrm{ka}$ et al. (1997). Semisynthetic diets contained ground pea as the only source of protein at a level corresponding to $95 \mathrm{~g}$ crude protein per $\mathrm{kg}$. Each diet was fed to eight four-week old male $\mathrm{IF}_{z}: \mathrm{JAZ}$ rats, with mean initial body weight $79 \mathrm{~g}$. Net protein utilization $(\mathrm{NPU}=\mathrm{BV} \times \mathrm{TD})$ and utilizable protein content $(\mathrm{NPV}=\mathrm{NPU}$ $\mathrm{x}$ CP, \%) were calculated.

In experiment 2 apparent metabolizable energy value (AME) was measured on six-weeks old male $\mathrm{IF}_{z}: \mathrm{JAZ}$ rats, with mean initial body weight of $101 \mathrm{~g}$. Basal diet was composed of (in $\mathrm{g} / \mathrm{kg}$ ): cereals, 618; soyabean oil meal, 150; fish meal, 80 ; milk powder, 100 ; soya oil, 20 ; mineral-vitamin mixture, 32 . Test diets contained per $\mathrm{kg}: 400 \mathrm{~g}$ of basal diet and $600 \mathrm{~g}$ of ground pea. Basal diet was fed to 14 rats, test diets were fed to 8 rats each in amount $13-15 \mathrm{~g}$ per day. After 4 days of preliminary period faeces were collected quantitatively for 6 days. The faeces were 
kept at $-18^{\circ} \mathrm{C}$ for further analysis. AME of the peas was calculated by the difference method using the values obtained for basal diet as a reference. At the end of experiment rats were killed by $\mathrm{CO}_{2}$ overdosing, the pancreas and caecum were dissected, caecal digesta were collected, the weight of pancreas, full and empty caccum and $\mathrm{pH}$ of caecal contents were measured.

\section{In vitro tests}

In all nine cultivars of pea seeds predicted apparent ileal digestibility of protein for pigs (pdN) was evaluated by in vitro method according to Boisen and Fernandez (1995), and predicted total tract digestibility of energy for pigs (pdE) by in vitro method according to Boisen and Fernandez (1997).

\section{Chemical and statistical analysis}

Weight of thousand seeds was determined, representative samples of seeds were dehulled and the percentage of hulls was calculated. Chemical composition of the seeds was determined according to AOAC (1990), neutral-detergent fibre (NDF), acid detergent fibre (ADF) and acid detergent lignin (ADL) content according to Van Soest and Wine (1967) and Van Soest (1973) on a Fibertec M (Tecator) apparatus. Amino acids analysis of protein was performed with an automatic Beckman 6300 High Pressure Amino Acid Analyzer after acid hydrolysis. Methionine and cystine were determined after oxidation with performic acid and tryptophane after hydrolysis with $\mathrm{BaOH}$ according to Buraczewska and Buraczewski (1981). Trypsin inhibitor activity was analyzed according to Kakade et al. (1974). Tannin content in pea seeds and hulls was evaluated according to the method of Jerumanis (1972) modified by Adams and Novellie (1975). Excreta of chickens prior to analysis were dried in a forced-draft oven at $70^{\circ} \mathrm{C}$ for $24 \mathrm{~h}$. Chemical composition of diets and excreta was determined according to AOAC (1990), fat in chickens diets and excreta was extracted with diethyl ether after acid hydrolysis. Gross energy was determined by Parr adiabatic oxygen bomb calorimeter KL-10. Chromic oxide in diets and excreta was analyzed spectrophotometrically following wet ashing according to Hinsberg et al. (1953). Faecal $\mathrm{N}$ in excreta of chickens was determined according to Ekman et al. (1949).

Statistical evaluation of results was done by Statgraphic plus ver. 7 Software.

\section{RESULTS}

The seeds of white-flowered varieties were on average bigger than those of coloured-flowered ones, however in both types there were cultivars with small and big seeds. The white-flowered cultivars had on average lower percentage of seed 
coat and lower content of dietary fibre than the coloured-flowered cultivars (Table 1). The content of protein and starch was higher in white-flowered cultivars, but there were no distinct differences in the content of other nutrients between both types of pea (Table 2). Lysine content in 8 cultivars averaged 7.46, only in the Agra cv. was below $7 \mathrm{~g} / 16 \mathrm{~g} \mathrm{~N}$. Methionine and cystine content was on average 0.96 and $1.49 \mathrm{~g} / 16 \mathrm{~g} \mathrm{~N}$, respectively. There were no big differences in remaining amino acid content between cultivars (Table 3). Trypsin inhibitor activity was low (from 0.96 to 2.37 TIU/mg DM) and did not differ significantly between whiteand coloured-flowered cultivars. Tannin content in white-flowered cultivars was very low and uniform $(0.25 \mathrm{~g} / \mathrm{kg}$ DM on average), in coloured-flowered significantly higher (7.26-12.1 g/kg DM). Most of tannins were present in seed coat (Table 2). Proportion of seed coat in coloured-flowered cultivars was bigger than in white-flowered and there was significant positive correlation between tannin content and percentage of hulls in seeds $(\mathrm{r}=0.96 ; \mathrm{P}<0.01)$.

In chickens apparent protein digestibility differed significantly between whiteand coloured-flowered cultivars, but apparent fat digestibility was significantly lower only for Żuraw cv. The $\mathrm{AME}_{\mathrm{N}}$ value for chicken and metabolizability of energy of white-flowered peas was on average $12.86 \mathrm{MJ} / \mathrm{kg} \mathrm{DM}$ and $64.5 \%$, and differed from the values of coloured-flowered peas which were significantly

TABLE 1

Seed dimensions, percentage of hulls in seeds and fibre fraction content in seeds, $g / \mathrm{kg}$ DM

\begin{tabular}{lccccccc}
\hline Pea cultivar & $\begin{array}{c}\text { Weight } \\
\text { l000 seeds g }\end{array}$ & $\begin{array}{c}\text { \% hulls } \\
\text { in seeds }\end{array}$ & $\begin{array}{c}\text { Crude } \\
\text { fibre }\end{array}$ & NDF & ADF & ADL & $\begin{array}{c}\text { Dietary } \\
\text { fibrc }\end{array}$ \\
\hline $\begin{array}{l}\text { White-flowered (WF) } \\
\quad\end{array}$ & 259 & 8.94 & 70 & 150 & 97 & 5.1 & 185 \\
$\quad$ Mazurck & 287 & 8.16 & 66 & 152 & 90 & 5.0 & 191 \\
Albatros & 192 & 8.92 & 69 & 169 & 95 & 3.7 & 183 \\
Agra & 282 & 7.61 & 59 & 126 & 78 & 4.2 & 186 \\
Piast & & & & & & & \\
& 255 & 8.41 & 66 & 149 & 90 & 4.5 & 186 \\
Average (WF) & & & & & & & \\
Coloured-flowered (CF) & & & & & & & \\
Bart & 255 & 10.32 & 75 & 172 & 98 & 7.4 & 230 \\
Idol & 195 & 10.53 & 69 & 164 & 95 & 7.3 & 181 \\
Dawo & 300 & 9.75 & 61 & 169 & 93 & 6.5 & 213 \\
Wiato & 211 & 9.63 & 66 & 149 & 90 & 6.1 & 199 \\
Zuraw & 193 & 10.64 & 67 & 160 & 92 & 7.0 & 207 \\
& & & & & & & \\
Averagc (CF) & 240 & 10.17 & 68 & 163 & 94 & 6.9 & 206 \\
\hline
\end{tabular}

' calculated as: $\mathrm{DF}=100$ - crude protein - ash - fat - starch - sugars 
TABLE 2

Chemical composition of peas and tannin content, g/kg DM, and trypsin inhibitor activity, TIU/mg DM

\begin{tabular}{lccccccccc} 
Pea cultivar & $\begin{array}{c}\text { Dry } \\
\text { matter }\end{array}$ & $\begin{array}{c}\text { Crude } \\
\text { protein }\end{array}$ & $\begin{array}{c}\text { Crude } \\
\text { ash }\end{array}$ & $\begin{array}{c}\text { Ether } \\
\text { extract }\end{array}$ & Sugars & Starch & \multicolumn{2}{c}{ Tannins } \\
in seeds & in hulls & TIU \\
\hline $\begin{array}{l}\text { White-flowered }(W F) \\
\text { Mazurek }\end{array}$ & 885 & 240 & 34 & 11 & 457 & 73 & 0.27 & 0.35 & 1.97 \\
Albatros & 884 & 237 & 32 & 9 & 461 & 70 & 0.22 & 0.37 & 0.96 \\
Agra & 893 & 229 & 35 & 14 & 493 & 46 & 0.27 & 0.34 & 2.33 \\
Piast & 878 & 205 & 34 & 16 & 495 & 64 & 0.23 & 0.30 & 2.06 \\
& & & & & & & & & \\
Average (WF) & 885 & 228 & 34 & 12 & 476 & 63 & 0.25 & 0.34 & 1.83 \\
Coloured-flowered (CF) & & & & & & & & & \\
Bart & 891 & 210 & 33 & 14 & 442 & 71 & 7.76 & 80.9 & 1.61 \\
Idol & 888 & 218 & 29 & 11 & 493 & 68 & 8.49 & 81.3 & 1.94 \\
Dawo & 884 & 194 & 30 & 12 & 489 & 62 & 7.26 & 72.3 & 2.32 \\
Wiato & 885 & 225 & 32 & 11 & 468 & 65 & 7.92 & 83.8 & 2.37 \\
Zuraw & 878 & 238 & 34 & 12 & 445 & 64 & 12.11 & 103.7 & 1.89 \\
Average (CF) & 885 & 217 & 32 & 12 & 467 & 66 & 8.71 & 84.4 & 2.03 \\
\hline
\end{tabular}

TABLE 3

Amino acid composition of pca protein, $g / 16 \mathrm{gN}$

\begin{tabular}{|c|c|c|c|c|c|c|c|c|c|}
\hline \multirow{3}{*}{$\begin{array}{l}\text { Amino } \\
\text { acid }\end{array}$} & \multicolumn{9}{|c|}{ Pea variety } \\
\hline & \multicolumn{4}{|c|}{ white-flowered } & \multicolumn{5}{|c|}{ coloured-flowered } \\
\hline & Mazurek & Albatros & Agra & Piast & Bart & ldol & Dawo & Wiato & Żuraw \\
\hline Lys & 7.36 & 7.40 & 6.93 & 7.56 & 7.54 & 7.42 & 7.59 & 7.48 & 7.36 \\
\hline Met & 0.92 & 0.92 & 1.02 & 1.02 & 0.99 & 0.96 & 0.97 & 0.95 & 0.91 \\
\hline Cys & 1.45 & 1.27 & 1.60 & 1.64 & 1.50 & 1.46 & 1.55 & 1.49 & 1.48 \\
\hline Thr & 3.83 & 3.95 & 3.70 & 3.96 & 4.06 & 3.93 & 4.02 & 3.84 & 3.77 \\
\hline $\operatorname{Trp}$ & 0.91 & 0.95 & 0.98 & 0.96 & 0.97 & 0.96 & 0.96 & 0.94 & 0.92 \\
\hline Ile & 4.23 & 4.17 & 3.96 & 4.33 & 4.34 & 4.23 & 4.30 & 4.25 & 4.20 \\
\hline Val & 4.82 & 4.79 & 4.66 & 5.12 & 4.91 & 4.86 & 4.83 & 4.82 & 4.76 \\
\hline Leu & 7.37 & 7.40 & 6.86 & 7.60 & 7.64 & 7.38 & 7.54 & 7.47 & 7.33 \\
\hline Tyr & 3.28 & 3.18 & 3.17 & 3.30 & 3.27 & 3.35 & 3.29 & 3.30 & 3.22 \\
\hline Phe & 4.91 & 4.85 & 4.65 & 4.95 & 5.09 & 4.96 & 5.08 & 5.01 & 4.95 \\
\hline $\mathrm{His}$ & 2.47 & 2.48 & 2.39 & 2.68 & 2.48 & 2.51 & 2.44 & 2.49 & 2.49 \\
\hline Arg & 8.69 & 9.46 & 8.54 & 8.87 & 7.96 & 8.63 & 7.88 & 8.73 & 9.05 \\
\hline Asp & 12.18 & 12.40 & 11.01 & 12.20 & 11.84 & 12.11 & 12.10 & 12.18 & 12.28 \\
\hline Ser & 4.78 & 4.97 & 4.66 & 5.01 & 4.90 & 4.82 & 4.93 & 4.84 & 4.87 \\
\hline Glu & 17.55 & 17.31 & 16.44 & 17.69 & 17.04 & 17.23 & 17.13 & 17.26 & 17.55 \\
\hline Pro & 4.00 & 3.97 & 4.03 & 4.20 & 4.04 & 4.04 & 4.04 & 4.09 & 4.03 \\
\hline Gly & 4.34 & 4.35 & 4.42 & 4.68 & 4.51 & 4.44 & 4.48 & 4.39 & 4.37 \\
\hline Ala & 4.31 & 4.36 & 4.25 & 4.53 & 4.52 & 4.38 & 4.44 & 4.32 & 4.26 \\
\hline
\end{tabular}


$(\mathrm{P}<0.05$ ) lower: $12.27 \mathrm{MJ} / \mathrm{kg} \mathrm{DM}$ and $61.5 \%$ respectively (Table 4). Inclusion $50 \%$ of pea into diet did not affect significantly the viscosity of jejunal digesta or $\mathrm{pH}$ of ileal digesta in chickens (Table 4). Enzyme supplementation of basal diet lowered significantly the viscosity of jejunal digesta by about $30 \%$ and $\mathrm{pH}$

TABLE 4 Apparent digestibility of crude protein (CPD) and crude fat (CFD), organic matter retention (OMR) and metabolizable energy $\left(\mathrm{AME}_{\mathrm{N}}\right.$ ) of basal diets and pea $\mathrm{cvs}^{\prime}$, viscosity of jejunal digesta and $\mathrm{pH}$ of ileal digesta in chickens

\begin{tabular}{|c|c|c|c|c|c|c|}
\hline $\begin{array}{l}\text { Pca cv and type } \\
\text { of basal diet }\end{array}$ & $\begin{array}{c}\mathrm{CPD} \\
\%\end{array}$ & $\begin{array}{c}\mathrm{CFD} \\
\%\end{array}$ & $\begin{array}{c}\text { OMR } \\
\%\end{array}$ & $\begin{array}{c}\mathrm{AME}_{\mathrm{N}} \\
\mathrm{MJ} / \mathrm{kg} \\
\mathrm{DM}\end{array}$ & $\begin{array}{c}\text { Viscosity of } \\
\text { jejunal digesta, } \mathrm{cP}\end{array}$ & $\begin{array}{l}\mathrm{pH} \text { of ileal } \\
\text { digesta }\end{array}$ \\
\hline Basal (A) & 89.4 & 78.6 & 71.9 & 13.94 & 2.27 & 7.75 \\
\hline Basa! (B) & 90.0 & $80.7^{x}$ & 72.4 & $14.13^{x}$ & $1.62^{x}$ & 7.29 \\
\hline Albatros (A) & 87.8 & 62.3 & 63.2 & 12.72 & 2.36 & 7.46 \\
\hline Albatros (B) & 88.1 & 68.9 & 66.7 & 12.91 & 1.93 & 7.78 \\
\hline Piast (A) & 83.5 & 60.9 & 68.3 & 12.94 & 2.48 & 7.44 \\
\hline Piast (B) & 83.4 & 62.0 & 67.5 & 12.88 & 1.84 & 7.70 \\
\hline Idol (A) & 79.6 & 62.1 & 64.7 & 12.53 & 2.56 & 7.80 \\
\hline Idol (B) & 80.7 & 66.3 & 63.1 & 12.21 & 1.95 & 7.49 \\
\hline Wiato $(A)$ & 78.3 & 65.9 & 65.2 & 12.30 & 2.43 & 7.46 \\
\hline Wiato (B) & 77.2 & 62.2 & 65.8 & 12.39 & 1.62 & 7.59 \\
\hline Żuraw (A) & 73.9 & 55.3 & 61.0 & 11.99 & 2.39 & 7.72 \\
\hline Żuraw (B) & 75.5 & 56.0 & 64.2 & 12.22 & 1.95 & 7.81 \\
\hline SEM & 0.56 & 2.14 & 0.80 & 0.14 & 0.21 & 0.13 \\
\hline Source of variation & \multicolumn{6}{|c|}{ Probability } \\
\hline Cultivar & 0.001 & 0.001 & 0.001 & 0.001 & 0.845 & 0.421 \\
\hline Enzyme & 0.347 & 0.522 & 0.070 & 0.787 & $0.001^{2}$ & 0.243 \\
\hline Enzyme $\mathrm{x} \mathrm{cV}$ & 0.147 & 0.093 & 0.004 & 0.277 & 0.869 & 0.155 \\
\hline & \multicolumn{6}{|c|}{ Means of pea cultivars } \\
\hline Albatros ${ }^{w}$ & $88.0^{a}$ & $65.7^{\mathrm{an}}$ & $65.0^{\mathrm{b}}$ & $12.82^{\mathrm{BBC}}$ & 2.14 & 7.62 \\
\hline Piast w & $83.5^{\mathrm{b}}$ & $61.5^{\mathrm{abAB}}$ & $67.9^{\mathrm{a}}$ & $12.91^{\mathrm{bc}}$ & 2.16 & 7.57 \\
\hline Idol $^{R}$ & $80.1^{*}$ & $64.2^{\mathrm{an}}$ & $63.9^{\mathrm{bc}}$ & $12.37^{\mathrm{AAB}}$ & 2.26 & 7.64 \\
\hline Wiato ${ }^{R}$ & $77.8^{\mathrm{d}}$ & $63.9^{\mathrm{a \Lambda}}$ & $65.5^{\mathrm{b}}$ & $12.35^{\mathrm{A} \mathrm{B}}$ & 2.02 & 7.53 \\
\hline Żuraw ${ }^{p}$ & $74.7^{e}$ & $55.7^{\text {bз }}$ & $62.6^{4}$ & $12.10^{\mathrm{aA}}$ & 2.17 & 7.77 \\
\hline
\end{tabular}

${ }^{W}$ white; ${ }^{R} \mathrm{red} ;{ }^{\mathrm{P}}$ - purple-flowered; 'values of CPD, CFD, OMR and AME $\mathrm{N}_{\mathrm{N}}$ for pea cultivars were calculated by difference method with the use as a reference the values obtained for basal diets $A$ or $B$

$x$ values obtained for basal diet $B$ significantly differs from diet $A(P<0.05)$; ${ }^{a} A A B$ means in columns with different superseripts are significantly different: ${ }^{\mathrm{b} b}$ at $\mathrm{P}<0.05 ;{ }^{\mathrm{AB}}$ at $\mathrm{P}<0.0$ l

2 mean viscosity for groups fed diets without enzymes was 2.44 ; for groups fed dicts supplemented with enzyme $1.86 \mathrm{cP}$ 
of ileal digesta by $5 \%$; fat digestibility and $\mathrm{AME}_{\mathrm{N}}$ value of basal diet increased significantly $(\mathrm{P}<0.05)$, but apparent protein digestibility and organic matter retention was not affected. Enzyme supplementation of test diets also significantly lowered viscosity of digesta by $24 \%$ on average, but did not affect significantly $\mathrm{pH}$ of jejunal digesta, $\mathrm{AME}_{\mathrm{N}}$ value of peas or digestibility of their components (Table 4).

In rats the digestibility of protein of white-flowered peas was significantly higher than coloured-flowered cultivars (on average 85 vs $79.5 \%$; $<0.05$ ). In contrast the biological value of protein in 5 cultivars was similar and averaged 86 , and only the BV of protein of the Idol cultivar was significantly higher (Table 5). The NPU value of the purple-flowered Żuraw cv. was significantly lower from white-flowered cv. Albatros and Piast and the red-flowered cv. Idol. The AME value for rats of white-flowered peas was on average $16 \mathrm{MJ} / \mathrm{kg}$ DM what means 1 to $2 \mathrm{MJ} / \mathrm{kg}$ higher than of coloured-flowered peas $(\mathrm{P}<0.05)$. After inclusion of red-flowered peas into diet, $\mathrm{pH}$ of caecal digesta was significantly $(\mathrm{P}<0.05)$ higher than on diets with white-flowered peas (Table 5).

Predicted values of ileal digestibility of protein and energy in pigs determined in vitro differed, pdN and pdE averaged respectively (in \%): 86.2 and 85.4 for white-, 77.8 and 82.1 for red-, 73.5 and 77.4 for purple-flowered pea (Table 6).

\section{DISCUSSION}

The protein content in evaluated peas was lower than reported by Gdala et al. (1992) and Zduńczyk et al. (1997), but amino acid profile of protein agrees well with the values reported in both papers and with the mean values published by

TABLE 5

Indices of nutritional value of protein, metabolizable energy value of pea, $\mathrm{pH}$ of caccal digesta and weight of pancreas $(\mathrm{g} / 100 \mathrm{~g}$ body weight) of rats fed diets with seeds of different pea cultivars

\begin{tabular}{lccccccc}
\hline $\begin{array}{l}\text { Pea } \\
\text { cultivar }\end{array}$ & $\begin{array}{c}\text { Protein } \\
\text { digestibility } \\
\text { (TD) \% }\end{array}$ & $\begin{array}{c}\text { Biological } \\
\text { value of } \\
\text { protein }\end{array}$ & $\begin{array}{c}\text { Net } \\
\text { protein } \\
\text { utilization }\end{array}$ & $\begin{array}{c}\text { Net } \\
\text { protein } \\
\text { value }\end{array}$ & $\begin{array}{c}\text { AME } \\
\text { MJ/kg } \\
\text { DM }\end{array}$ & $\begin{array}{c}\text { Weight of } \\
\text { pancreas }\end{array}$ & $\begin{array}{c}\text { pH of } \\
\text { caecal } \\
\text { digesta }\end{array}$ \\
\hline Albatros $^{\mathrm{w}}$ & $84.4^{\mathrm{b}}$ & $85.1^{\mathrm{a}}$ & $75.2^{\mathrm{c}}$ & 17.8 & $15.93^{\mathrm{c}}$ & 0.494 & $5.82^{\mathrm{a}}$ \\
Piast $^{\mathrm{w}}$ & $85.9^{\mathrm{b}}$ & $84.8^{\mathrm{b}}$ & $72.8^{\mathrm{bc}}$ & 14.9 & $16.11^{\mathrm{b}}$ & 0.503 & $5.77^{\mathrm{a}}$ \\
ldol $^{\mathrm{R}}$ & $79.9^{\mathrm{a}}$ & $92.1^{\mathrm{b}}$ & $73.6^{\mathrm{bc}}$ & 16.0 & $13.96^{\mathrm{a}}$ & - & - \\
Dawo $^{\mathrm{k}}$ & $78.6^{\mathrm{a}}$ & $88.9^{\mathrm{bb}}$ & $69.8^{\mathrm{bb}}$ & 13.5 & $15.07^{\mathrm{b}}$ & 0.507 & $6.14^{\mathrm{b}}$ \\
Wiato $^{\mathrm{R}}$ & $79.6^{\mathrm{a}}$ & $86.9^{\mathrm{a}}$ & $69.2^{\mathrm{b}}$ & 15.6 & $14.48^{\mathrm{ab}}$ & 0.550 & $6.16^{\mathrm{b}}$ \\
Żuraw $^{\mathrm{b}}$ & $79.7^{\mathrm{a}}$ & $84.6^{\mathrm{a}}$ & $67.3^{\mathrm{b}}$ & 16.0 & $13.98^{\mathrm{a}}$ & 0.549 & $6.11^{\mathrm{b}}$ \\
SEM & 0.8 & 1.1 & 1.1 & 1.1 & 0.16 & 0.017 & 0.06 \\
\hline
\end{tabular}

w. R.P as in Table $4 ;^{a, b}-$ means in columns with different superscripts are significantly different at $\mathrm{P}<0.05$ 
TABLE 6

In vitro ileal digestibility of protein (pdN) and total tract digestibility of energy (pdE) for pigs, $\%$

\begin{tabular}{|c|c|c|}
\hline Pea cultivar & $\mathrm{pdN}$ & $\mathrm{pdE}$ \\
\hline Mazurek w & 86.7 & 80.9 \\
\hline Albatros $w$ & 86.5 & 83.2 \\
\hline Agraw & 85.9 & 89.4 \\
\hline Piast ${ }^{w}$ & 86.1 & 88.2 \\
\hline Bart $^{k}$ & 77.6 & 86.2 \\
\hline Idol $^{R}$ & 77.2 & 84.0 \\
\hline Dawo ${ }^{R}$ & 77.2 & 79.3 \\
\hline Wiato $^{\mathrm{k}}$ & 79.1 & 79.1 \\
\hline Żuraw $^{\mathrm{P}}$ & 73.6 & 77.4 \\
\hline
\end{tabular}

$W, R, P$ as in Table 4

WPSA (1992). The protein of evaluated cultivars had high lysine and low sulphur amino acid content. The lysine content in pea protein was about $45 \%$ higher than in meat meals, the sulphur-containing amino acids and threonine content was of the same order as in meat meals (WPSA, 1992). It makes pea a good substitute of meat meals in feed mixtures for growing chickens and pigs. In the context of meeting the dietary requirement of indispensable amino acids for poultry and pigs, cereal grains and peas are nutritionally complementary. The significantly higher biological value of protein of the Idol cv. could not be attributed to any difference in amino acid content. Mean trypsin inhibitor activity (TI) in all analyzed cultivars was $1.9 \mathrm{TIU} / \mathrm{mg}$ DM. The measured values were much lower and less variable than reported by Gdala et al. (1992), who found 5.1 in the white- and $8.9 \mathrm{TIU} / \mathrm{mg}$ DM in the coloured-flowered Polish cultivars from 1985-86 harvest years, and lower than reported by Zdunczyk et al. (1997). The last authors found $4 \mathrm{TIU} / \mathrm{mg}$ DM in white-flowered cultivars from 1992-1993 harvest year. Trypsin inhibitor activity in evaluated pea cultivars did not depend on the colour of flowers, similarly as in report of Bastianelli et al. (1998). It seems that Polish plant breeders succeeded in producing cultivars of pea of low activity of protease inhibitors. This means that one of the factors that may interfere with protein digestion in monogastric animals was nearly removed.

White-coloured cultivars were low in tannin, as was expected. Tannin content in coloured-flowered cultivars was higher, but within the limits reported by Gdala et al. (1992), Gdala and Buraczewska (1997) and Bastianelli et al. (1998). Statistical evaluation of results indicated, that of all determined components of pea seeds, tannins had the most pronounced negative effect on protein digestibility. Tannin content affected negatively protein digestibility in chicken $(r=-0.93 ; \mathrm{P}<0.05)$ and rats $(\mathrm{r}=-0.89 ; \mathrm{P}<0.05)$ and ileal digestibility of protein for pigs determined in vitro $(\mathrm{r}=-0.98 ; \mathrm{P}<0.001)$. It agrees well with reports of other authors (Lindgren, 1975; 
Gdala et al., 1992; Grosjean, 1999), who found significant differences in digestibility of protein between white- and coloured-flowered cultivars. The phenolic groups of tannins bind to enzymes and other proteins and form insoluble tanninprotein complexes resistant to digestive enzymes of monogastric animals, hydrogen bonds and hydrophobic interactions appear to be the principal linkages involved (Artz et al., 1987).

The BV of protein of evaluated cultivars was not correlated with tannin content, what indicates that tannins did not bind specifically with any limiting amino acid in pea protein. However NPV of evaluated cultivars depended less on the tannin content and was correlated negatively with trypsin inhibitor activity $(r=-0.84$; $\mathrm{P}<0.05$ ), Due to relatively high protein content, the NPV of the Zuraw cv. was the same as NPV of the Idol cv. and higher than Piast cv. despite the differences in protein digestibility.

Metabolizable energy for chicken of white-flowered cultivars averaged 12.86, for coloured-flowered $12.27 \mathrm{MJ} / \mathrm{kg} \mathrm{DM}$ and were in the range of the values obtained by Grosjean et al. (1999) on adult cockerels (13.18 and 12.72 MJ/kg DM, respectively) and by Grosjean et al. (1998b) on broiler chickens (on average $12.24 \mathrm{MJ} / \mathrm{kg} \mathrm{DM}$ for white-coloured tannin-free peas). The last authors noted considerable variability in metabolizable energy for broiler chicken of 26 analyzed pea batches (from 11.66 to $12.95 \mathrm{MJ} / \mathrm{kg} \mathrm{DM}$ ), but the correlation between chemical composition criteria and energy values were weak. Similarly in this study, nutrient and dietary fibre content had no significant effect on metabolizable energy value in evaluated cultivars, while tannin content affected negatively $\mathrm{AME}_{\mathrm{N}}$ value for chicken $(\mathrm{r}=-0.99 ; \mathrm{P}<0.001)$ and $\mathrm{AME}$ for rats $(\mathrm{r}=-0.95 ; \mathrm{P}<0.01)$. Protein digestibility, $\mathrm{AME}_{\mathrm{N}}$ values in chickens and $\mathrm{AME}$ in rats were also correlated with hulls content in seeds. Coloured-flowered varieties had proportionally more seed coat and higher tannin content, which are mostly present in the hulls.

In chickens due to substitution of half of the basal diet by pea, the viscosity of intestinal digesta increased slightly (on average by $7 \%$ ). After supplementation of basal and test diets with xylanase the viscosity of digesta decreased significantly $(\mathrm{P}<0.001)$, but probably the dietary fibre of pea was resistant to the added enzyme, as the difference in viscosity between the basal and pea-containing groups extended (to $15 \%$ on average). Igbasan et al. (1997) found, that in the components of non-starch polysaccharides (NSP) of Canadian pea cultivars predominates glucose, followed by uronic acids, arabinose, xylose and galactose (on average 47 , $22,19,6$ and $4 \%$ of total NSP, respectively). The relatively high concentrations of uronic acids and arabinose residues indicate that pectic-type substances are important components of the cell wall of peas. The results of the present experiment proves that the effect of pectic substances of pea on viscosity of digesta in chicken may be neglected, as it did not affect the energy and protein values (Table 4). 
Significantly higher $\mathrm{pH}$ values of caecal digesta in rats fed on colour-flowered pea (Table 5) indicates for an effect of tannins on caecal fermentation. Lower intensity of fermentation may result either from direct inhibitory effect of tannins on microflora or from greater amount of nondigested protein of dietary and endogenous origin reaching large intestine.

Predicted total tract digestibility of energy in pigs (pdE) averaged $85 \%$ for 4 white- and 2 cultivars of red-flowered pea, $79 \%$ for remaining 2 red-flowered cultivars and $77 \%$ for purple-flowered pea. PdE was not correlated with predicted ileal digestibility of protein $(\mathrm{pdN})$, nor with tannin or nutrient content in seeds. Grosjean et al. (1998a) reported that apparent digestibility of energy in pigs was $89 \%$ for white- and $81 \%$ for coloured-flowered pea. The lower pdE value of the Zuraw cultivar was undoubtedly due to the high tannin content.

The lack of correlation of trypsin inhibitor activity with the relative weight of pancreas in rats confirms the results obtained on chickens, rats and in in vitro evaluation, that at the level present in evaluated cultivars trypsin inhibitors had not affected digestibility of protein. Al-Wesali et al. (1995) have demonstrated that in vitro purified trypsin inhibitor of pea had a far less inhibitory effect on casein digestibility than has soyabean trypsin inhibitor. However recently Hedemann et al. (1999) found, that in lines of pea which have 4-5 times more TI not only digestibility in rats, but also biological value of protein have been lowered in comparison with near-isogenic lines low in TI. It indicates, that trypsin inhibitor activity in new cultivars of pea should be continuously controlled.

The results indicate, that tannins present in colour-flowered pea may lower the digestibility of protein and metabolizability of energy in monogastric animals, while the role of dietary fibre and trypsin inhibitors in modern spring cultivars of pea is of smaller importance. However the amount of protein available to animals depends as well on the protein content in the seed. It seems that high protein content is the most important criterium of usefulness of pea in nutrition of monogastric animals nutrition but both the activity of TI and tannin content in new pea cultivars should be also monitored.

\section{CONCLUSIONS}

White flowered peas are digested better than coloured flowered peas. The digestibility is depressed by the presence of tannins. Lowering the tannin content should be included into breeding programs of new cultivars of pea, as the nutrients of high-tannin seeds are less effectively utilized by monogastric animals. 


\section{REFERENCES}

Adams C.A., Novellie K., 1975. Composition and structure of protein bodies and spherosomes isolated from ungerminated seeds of Sorghum bicolor (Linn). Mun. Plant Physiol. 55, 1-6

Al-Wesali M., Lambert N., Welham T., Hedley C., Domoney C., 1995. Evaluation of pea seed trypsin inhibitors in in vitro protein digestibility studies. Proceedings of $2^{\text {nd }}$ European Conference on Grain Legumes, Copenhagen (Denmark), pp. 290-291

AOAC, 1990. Official Methods of Analysis. Association of Official Analytical Chemists. $15^{\text {th }}$ Edition. Washington, DC

Artz W.E., Bishop P.D., Dunker A.K., Schanus E.G., Swanson B.G., 1987. Interaction of synthetic proathocyanidin dimer and trimer with bovine serum albumin and purified bean giobulin fraction G-1. J. Agr. Food Chem. 35, 417-421

Bastianelli D., Grosjean F., Peyronnet C., Duparque M., Regnier J. M., 1998. Feeding value of pea (Pisum sativum, L.) 1. Chemical composition of different categories of pea. Anim. Sci. 67, 609619

Boisen S., Fernandez J. A., 1995. Prediction of the apparent ileal digestibility of protein and anino acids in feedstuffs and feed mixtures for pigs by in vitro analyses. Anim. Feed Sci. Tech. 51 , $29-43$

Boisen S., Fernandez J. A., 1997. Prediction of the total tract digestibility of energy in feedstuffs and pig diet by in vitro analyses Anim. Feed Sci. Tech. 68, 277-286

Buraczewska L., Buraczewski S., 1981. A note on determination of methionine and tryptophan. $\ln$ : Proceedings of the 6th International Symposium on Amino Acids, Serock (Poland), pp. 47-50

Campbeil G. L., Campbell L. D., Blair R., 1983. Calculation of metabolizable energy for ingredients incorporated at low levels into a reference diet. Poultry Sci. 62, 705.707

Ekman P., Emanuelson H., Fransson A., 1949. The digestibility of protein in poultry. Kungl. Lantbruks.Hogskol. Ann. 16, 749

Gdala J., Buraczewska L., Grala W., 1992. The chemical composition of different types and varieties of pea and the digestion of their protein in pigs. J. Anim. Feed Sci. 1, 71-79

Gdala J., Buraczewska L., 1997. lieal digestibility of pea and faba bean carbohydrates in growing pigs. J. Anim. Feed Sci. 6, 235-245

Grosjcan F., Barrier-Guillot B., Bastianelli D., Rudeaux F., Bourdillon A., Peyronnet C., 1999. Feeding value of three categories of pea (Pisum sativim, L.) for poultry. Anim. Sci. 69, 591-599

Grosjean F., Bastianelli D., Bourdillon A., Cerneau P., Jondreville C., Peyronnet C., 1998a. Feeding value of pea (Pistim sativum, L.) 2. Nutritional value in the pig. Anim. Sci. 67,621-625

Grosjean F., Williatte-Hazouard I., Barrier-Guillot B., Skiba F., Metayer J. P., Pcyronnet C., Gatel F., 1998b. Variability of energy value of pea for pigs and broiler chickens: Attempts to identify effects of environmental conditions and agricultural practices. Proccedings of $3^{\text {rd }}$ European Conference on Grain Legumes, Valladolid (Spain), pp. 304-305

Hedemann M. S., Welham T., Boisen S., Canibe N., Bilham L., Demoney C., 1999. Studies on the biological responses of rats to secd trypsin inhibitors using near-isogenic lines of Pisum sativum L. (pea). J. Sci. Food Agr: 79, 1647-1653

Hinsberg K., Cremer H.D., Schmid G., 1953. In: Hoppe-Seyler/Thierfelder-Handbuch der Physiologisch-und Patologisch-Chemischen Analyse. Springer-Verlag, Vol. 5, 402-403

Igbasan F. A., Guenter W., Slominski B.A., 1997. Field peas: Chemical composition and energy and amino acid availabilities for poultry. Can. J. Anim. Sci. 77, 293-300

Jerumanis J., 1972. Über die Veranderung der Polyphenole in Verlauf des Malzens und Maischens. Brauwissenschaft 25, 313-322 
Kakade M. C., Rackis J. J., McGhec J. E., Puski G., 1974. Determination of trypsin inhibitor activity of soy products: collaborative analysis of an improved procedure. Cereal Chem. 51, 376-382

Lindgren E., 1975. The nutritive value of peas and field beans for hens. Swed. J. Agr. Res. 5, 159-161

Pesti G. M., Ware G. O., 1986. Expressing the variability in results of metabolizable energy assays. J. Nutr. 116, 1385-1389

Savage G. P., 1989. Antinutritive factors in peas. In: J. Huisman, T.F.B. van der Poel, I.E. Liener (Editors). Recent Advances of Research in Antinutritional Factors in Legume Seeds. Pudoc, Wageningen, pp. 342-350

Smulikowska S., Pastuszewska B., Mieczkowska A., Ochtabińska A., 1997. Chemical composition, energy value for chickens and protein utilization in rats of repeseed expeller cakes produced by different pressing technologies. J. Anim. Feed Sci. 6, 109-121

WPSA, 1992. European Amino Acid Table. W.M.M.A. Janssen, F.B.J.M. Ingelaat, Sj. Schaper, J. McNab (Editors). Publication of Working Group Nutrition, Beckbergen (The Netherlands)

Van Soest P.J., 1973. Collaborative study of acid detergent fiber and lignin. J. Assoc. Off. Anal. Chem. Int. 56, 781-782

Van Soest P.J., Wine R.H., 1967. Use of detergents in the analysis of fibrous feeds. IV. Determination of plant cell-wall constituents. J. Assoc. Ofr. Agric. Chem. Int. 50, 50-55

Zduńczyk Z., Godycka I., Amarowicz R., 1997. Chemical composition and content of antinutritional factors in Polish cultivars of peas. Plant Food Hum. Nutr. 50, 37-45

Wiatr K., 1999. Pea. Results of cultivar testing (in Polish). COBORU (Editor). Słupia Wielka (Poland)

\section{STRESZCZENIE}

\section{Taniny obniżają wartość odżywezą nasion grochu dla zwierząt monogastrycznych}

W dziewięciu polskich odmianach grochu (P. sativum L.) różniących się barwą kwiatów, od białej do fiolctowej, oznaczono skład chemiczny i skład aminokwasowy białka. Przewidywaną strawność białka (jelitowa, pdN) i energii (pdE) u świń oznaczono metodą in vitro. W 5 odmianach grochu, różniących się zawartością tanin, oznaczono u kurcząt brojlerów wartość pozorncj energii metabolicznej $\left(\mathrm{AME}_{N}\right.$ ) oraz pozorna strawność białka i tłuszczu diet nieuzupełnionych lub uzupełnionych ksylanazą. Wartość energii metaboliczncj (AME), strawność i wartość biologiczną białka 6 odmian grochu oznaczono na szczurach. Stwierdzono, że zawartość tanin w nasionach grochu była ujemnie skorelowana ze strawnością białka u kurcząt $(r=-0,93 ; \mathrm{P}<0,05)$, szczurów $(\mathrm{r}=-0,89$; $\mathrm{P}<0,05)$ i świń $(\mathrm{r}=-0,98, \mathrm{P}<0,001)$ oraz $\mathrm{z}$ wartością $\mathrm{AME}_{\mathrm{N}}$ dla kurcząt $(\mathrm{r}=-0,99, \mathrm{P}<0,001)$ i wartością AME dla szczurów ( $\mathrm{r}=-0,95, \mathrm{P}<0,01)$. Różnice w zawartości składników odżywczych między odmianami były niewielkie i nie wpływały w sposób istotny na mierzone wskaźniki wartości odżywczej nasion grochu. Uzupełnienie diety ksylanazą nie wpłynçło na wartość $\mathrm{AME}_{\mathrm{N}}$ nasion grochu dla kurcząt.

Nasiona grochów kolorowo kwitnących są mniej efektywnie wykorzystywane przez zwierzęta monogastryczne niż nasiona odmian białokwitnących. Stopień obniżenia wykorzystania składników odżywczych grochu zależy od zawartości tanin, która jest skorelowana z barwą kwiatów. 